\title{
HAMBATAN ETIL P-METOKSI SINAMAT DARI RIMPANG KAEMPFERIA GALANGA TERHADAP PARASIT PLASMODIUM FALCIPARUM IN VITRO DAN AKTIFITAS ENZIM ATPase
}

Abdul Muis ${ }^{1}$, Ukun M.S. Soedjanaatmadja ${ }^{2}$, Supriyatna ${ }^{2}$, dan Syafruddin ${ }^{3}$

${ }^{1}$ Program Studi Biologi Fakultas Keguruan dan IImu Pendidikan Universitas Kuningan.

${ }^{2}$ Program Studi Kimia Fakultas Matematika \& IImu Pengetahuan Alam Universitas Padjadjaran.

${ }^{3}$ Eijkman Institute for Moleculer Biology. Jakarta.

\begin{abstract}
Abstrak
Dalam mempelajari senyawa antimalaria baru, telah dilakukan penelitian menggunakan etil $p$-metoksi sinamat dari rimpang Kaempferia galanga yang diuji aktivitasnya terhadap pertumbuhan parasit Plasmodium falciparum secara in vitro. Selanjutnya untuk mempelajari mekanisme kerja etil $p$-metoksi sinamat, dilakukan uji terhadap aktivitas enzim ATPase. Percobaan terhadap pertumbuhan Plasmodium falciparum menggunakan metode sigmaflot 2000, dan aktivitas enzim menggunakan metode spektrofotoskopi pada $\left(\lambda_{670 \mathrm{~nm}}\right)$. Hasil pecobaan menunjukan potensi etil $p$-metoksi sinamat terhadap pertumbuhan parasit diperoleh $\mathrm{IC}_{50}=50 \%$ sebesar $19,5 \mathrm{ngmL}^{-1}$ atau $94,6 \mathrm{nM}$. Hambatan aktivitas enzim tingkat signifikansi 2,2\% (signifikan), dan $0,7 \%$ (sangat signifikan) serta menunjukkan hambatan non-kompetitif dengan nilai $\mathrm{K}_{l}(0,09 \mathrm{mM})$.

Kata kunci

etil $p$-metoksi sinamat, Plasmodium falciparum, enzim ATPase.
\end{abstract}

\begin{abstract} value of $\mathrm{KI}(0.09 \mathrm{mM})$.

Keywords

ethyl-p-methoxycinnamic. Plasmodium falciparum. ATPase enzyme.
\end{abstract}

In the study of the new antimalarial compound, the research was conducted by using ethyl-pmethoxycinnamic from Kaempferia galanga whose activities were tested to the in vitro Plasmodium falciparum growth. Then, to study the ethyl-p-methoxycinnamic mechanism, ATPase enzymatic activities were subsequently tested. The experiment towards the Plasmodium falciparum growth used sigmaflot 2000 method, and the ATPase activities used spectroscopy method at $\lambda_{670 \mathrm{~nm}}$. The findings showed that a potent antimalarial activity of the ethyl-p-methoxycinnamic $I C_{50}$ is $19,5 \mathrm{ngmL}^{-1}$ or $94.6 \mathrm{nM}$. The inhibitions of enzyme activity showed $2.2 \%$ significant, and $0.7 \%$ highly significant and it showed non-competitive barriers to the

\section{Pendahuluan}

Penyakit malaria masih merupakan masalah kesehatan masyarakat di 107 negara yang dihuni oleh sekitar 3,2 milyar penduduk atau $40 \%$ dari total penduduk dunia. Prevalensi penyakit ini di dunia diperkirakan sekitar 300-500 juta kasus klinis setiap tahun [1]. Pencarian obat-obat antimalaria baru sampai saat ini masih terus berlangsung baik secara sintetik maupun melalui penelitian bahan alam yang secara empiris telah dikenal sebagai antimalaria. Dari hasil penelitian terdahulu ditemukan adanya aktivitas antimalaria dari ekstrak etanol rimpang $K$. galanga. Penelitian awal ini dilakukan secara in vitro menggunakan $P$. falciparum sebagai model percobaan, dimana pertumbuhan parasit secara nyata dihambat oleh ekstrak tersebut dengan $\mathrm{IC}_{50}=14,3 \mu \mathrm{g} \cdot \mathrm{mL}^{-1}$ [2]. Hasil penelitian [3] terungkap bahwa senyawa bioaktif yang terkandung dalam rimpang $K$. galanga antara lain (Gambar 1) adalah: etil-pmetoksisinamat

Penyakit malaria tropika disebabkan oleh parasit protozoa dari genus Plasmodium. $P$. falciparum merupakan species yang paling berbahaya karena penyakit yang ditimbulkan dapat menjadi fatal akibat komplikasi pada otak. Parasit ini terdapat di daerah tropik terutama Afrika dan Asia tenggara. Di Indonesia $P$. falciparum tersebar diseluruh kepulauan nusantara. Berbagai galur $P$. falciparum yang berasal dari daerah-daerah endemik malaria di dunia, misalnya: D-7, D-10, FCR-3, NF-4, telah berhasil diadaptasi untuk dibiakkan secara in vitro, sekaligus dijadikan 
sebagai model untuk mempelajari prosesproses dasar seluler dan molekuler dari organisme ini. Namun demikian, saat ini masih terdapat keterbatasan dalam melakukan penelitian in vivo terhadap parasit ini oleh karena adanya keterbatasan model hewan yang dapat diinfeksi oleh $P$. falciparum [4].

Perhitungan aktivitas antimalaria dilakukan untuk menentukan \% parasitemia dan efek inhibisi ekstrak, fraksi dan isolat murni yang di uji. Persen parasitemia adalah jumlah eritrosit yang terinfeksi parasit dibagi dengan jumlah eritrosit total dikali 100\%. [5], dapat dirumuskan sebagai berikut :

$$
\text { Persen parasitemia }=\frac{\text { Jumlah eritrosit terinfeksi parasit }}{\text { jumlah total eritrosit }} \times 100 \%
$$

Persen inhibisi diperoleh daeri pengurangan antara parasitemia kontrol dan parasitemia perlakuan, dibagi dengan parasitemia kontrol dan dikalikan dengan $100 \%$, atau seperti ditunjukkan pada persamaan berikut:

Persen inhibisi $=\frac{\text { parasitemia kontrol }- \text { parasitemia perlakuan }}{\text { parasitemia kontrol }} \times 100 \%$

Konsetrasi hambatan $50 \%\left(\mathrm{IC}_{50}\right)$ fraksi dan isolat murni ditentukan dengan analisis regresi linier menggunakan program komputer $\mathrm{Xp}$ Sigma-plot untuk menentukan konsentrasi penghambatan $50 \% \quad\left(\mathrm{IC}_{50}\right)$. Berdasarkan perpotongan garis $50 \%$, kurva yang dibentuk antara persen pertumbuhan sb- $y$ dan konsentrasi sb-x [5]. Perhitungan aktivitas dalam penelitian ini mengunakan metode analisis regresi linier program komputer $X p$ Sigma-plot [6].

Enzim adalah golongan protein paling banyak terdapat dalam sel hidup, berpungsi sebagai katalisator reaksi biomolekul, mengikat substrat dan menurunkan energi aktivasi. Kinetika enzim adalah cara mempelajari mekanisme kerja enzim dalam merubah substrat menjadi hasil reaksi [7].
Pendekatan analisis kinetika enzim yang paling dikenal adalah asas keseimbangan menurut Michaelis-Menten.

Selanjutnya ditranformasikan ke dalam bentuk linier dikenal dengan persamaan Lineweaver-Burk:

$$
1 / v=K_{m} /(S) \cdot 1 / V_{\max }+1 / V_{\max }
$$

Jika terjadi reaksi non competitive, maka dibuat persamaan garis Lineweaver-Burk:

$1 / v=1 / \mathrm{V}_{\max }\left\{1+(\mathrm{I}) / \mathrm{K}_{\mathrm{El}}\right\}+\mathrm{K}_{\mathrm{S}} / \mathrm{V}_{\max }\left\{1+(\mathrm{I}) / \mathrm{K}_{\mathrm{EI}}\right\} 1 /(\mathrm{S})$

Mekanisme kerja senyawa antimalaria terhadap aktivitas enzim tidak dapat diungkap langsung melalui Plasmodium, tetapi untuk percobaan menggunakan enzim ATPase (Sigma) hasil isolasi. Metode yang digunakan pada percobaan adalah metode spektrofotometri [8].

ATPase, Enzim ATPase berperan dalam aktivitas transpor ion pada membran plasma bagian dalam, seperti pada sitosol dan mitokondria. Selain itu berperan dalam hidrolisis ATP menjadi ADP dan fosfat anorganik.

$$
\text { ATP }-\longrightarrow A D P+P_{i}
$$

Dalam proses hidrolisis enzim yang bekerja adalah $\mathrm{Na}^{+}-\mathrm{K}^{+}$ATPase dan kofaktor $\mathrm{Mg}^{2+}$ karena berhubungan dengan transpor $\mathrm{Na}^{+} / \mathrm{K}^{+}[7]$

\section{Metodologi Penelitian}

Parasit diperoleh dari lembaga Eijkman Jakarta, kultur parasit $P$. falciparum klon 3D7 dipelihara secara in vitro dengan metode standar ( Trager and Jensen 1976). Kultur tersebut diinkubasi pada suhu $37^{\circ} \mathrm{C}$, dibiakkan dalam medium RPMI-1640 (Sigma-Aldrich) yang ditambah dengan hematokrit dan $10 \%$ $\mathrm{AB}^{+}$serum darah manusia. Bahan kimia diperoleh dari SIGMA digunakan untuk preparasi sampel pelarut-pelarut organik, pereaksi berkuatitas murni 


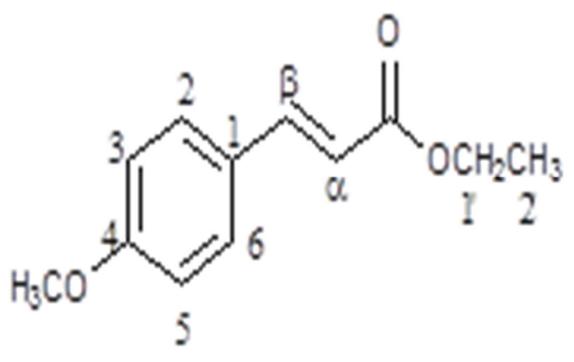

Gambar 1

Struktur molekul etil-p-metoksisinamat.

(p.a) atau yang dimurnikan. Pembuatan pereaksi enzimatik. Buffer suksinat $40 \mathrm{mM}$ dengan $4 \mathrm{mM}$ kalsium klorida dilarutkan dalam aquades ditambah kalium klorida. pH 6,6 dibuat dengan menambah kalium hidroksida. Larutan ATP 2,0 mM dibuat dalam $15 \mathrm{~mL}$ dengam pelarut buffer suksinat $\mathrm{pH} 7,2$. ATPase 1,5 unit dibuat dari melarutkan $1 \mathrm{mg} \cdot \mathrm{mL}^{-1}$ enzim ATPase dalam air dingin. Amonium Molibdat $10 \%$, dibuat larutan $100 \mathrm{~mL}$ ammonium molibdat dalam asam sulfat $10 \mathrm{~N}$. fenil hidrazindihidoklorida $0,1 \mathrm{M}$ diencerkan dia kali dan inhibitor senyawan 2 dibuat dalam larutan $1 \mathrm{mg} \cdot \mathrm{mL}^{-1}$ diencerkan 10 kali.

Uji etil-p-metoksisinamat in vitro. Uji aktivitas antimalaria isolat murni menggunakan plat kultur $(10 \times 10 \mathrm{~cm})$ yang memiliki 24 lubang, á $3 \mathrm{~mL}$. Ke dalam masingmasing sumur berturut-turut diisi larutan RPMI-1640, 10\% serum dan $50 \mathrm{~L} \mathrm{RBC}^{+}$(red blood concentrate) yang mengadung parasit $P$. falcifarum serta isolat yang akan diuji sedemikian rupa sehingga volume akhir mencapai $1 \mathrm{~mL}$. Plat kultur disimpan dalam inkubator suhu $27^{\circ} \mathrm{C}$ dan diamati setiap hari selama 3 hari. Untuk percobaan standar, 50 $\mu \mathrm{L}$ klorokuin (Sigma) dalam variasi konsentrasi $10^{-2}-10^{-9} \mathrm{M}$, secara berurutan dimasukkan ke dalam 8 sumur. Selanjutnya $50 \mu \mathrm{L}$ larutan senyawa uji pertama dengan variasi konsentrasi $10^{-2}-10^{-6} \mathrm{M}$ dimasukkan dalam 5 sumur berikutnya.Pertumbuhan parasit dimonitor tiap hari $\left(\mathrm{H}_{0}\right.$ sampai dengan $\left.\mathrm{H}_{3}\right)$, dengan cara mengoleskan 15 ?l kultur parasit pada gelas obyek dan kemudian dibuat apusan. Apusan darah tersebut difiksasi dengan metanol, dikeringkan dan diwarnai dengan larutan Giemsa 10\% selama 10 menit. Setelah dibilas dan dikeringkan, gelas obyek tersebut diperiksa di bawah mikroskop binokuler dan parasitemia dihitung di bawah perbesaran 1000x. Selanjutnya dilakukan penentuan konsentrasi hambatan $I_{50}$ Penentuan konstanta Michaels-Menten $\left(\mathrm{K}_{\mathrm{M}}\right)$ enzim ATPase. Penentuan $K_{m}$ ATPase dalam reaksi penguraian substrat adenosin trifosfat ATP menjadi ADP dan $\mathrm{P}_{\mathrm{i}}$, dilakukan berdasarkan metode spektrofotometri (Kernen et al., 1997), melalui beberapa langkah percobaan.

Langkah pertama persiapan bahan kimia percobaan, yaitu: Pembuatan larutan buffer suksinat $40 \mathrm{mM}$. pH 7,5; larutan enzim ATPase $1 \mathrm{mgmL}^{-1}$; larutan ATP 2,0 mM, pH 7,2; larutan amonium molibdat $10 \%$ dalam asam sulfat 10 $\mathrm{N}$ dan larutan fenilhidrazin dihidoklorida 0,1 M.

Langkah ke dua pelaksanaan percobaan yaitu campuran: substrat ATP $(100,200,300$, 400 dan $500 \mu \mathrm{L})$, enzim ATPase $(50 \mu \mathrm{L})$ dan ditambah buffer suksinat $(40 \mathrm{mM})$ untuk menyamakan volume, diinkubasikan dalam waterbath pada suhu $30^{\circ} \mathrm{C}$ selama 10 menit. Aktivitas enzim dihentikan dengan menambahkan $700 \mu \mathrm{L}$ ammonium molibdat (10\%), $300 \mu \mathrm{L}$ fenilhidrazin dihidoklorida $(0,1$ $\mathrm{mM})$ dan $400 \mu \mathrm{L}$ aquades, sehingga volume total menjadi $2 \mathrm{~mL}$, selanjutnya dipanaskan dalam penangas air $\left(100^{\circ} \mathrm{C}\right)$ selama 10 menit.

Langkah ke tiga pengamatan serapan yang diperoleh dari pemanasan variasi substrat pada suhu $\left(100^{\circ} \mathrm{C}\right)$ dan waktu 10 menit tersebut, segera didinginkan dan diukur serapannya pada spektrofotometer pada panjang gelombang $\lambda_{670 \mathrm{~nm}}$. Langkah keempat penentuan tetapan $K_{m}$ ATPase tehadap substrat ATP, dilakukan dengan menganalisis data secara statistik. 


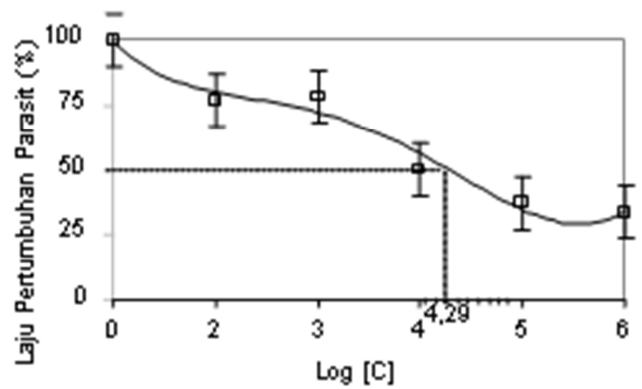

etil - $p$-metoksi sinamat

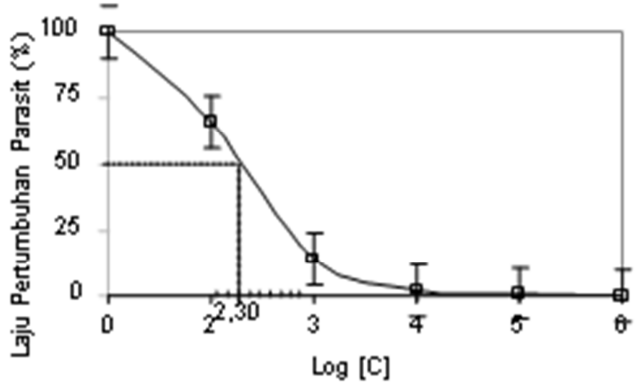

klorokuin

jambar 2 Pola pertumbuhan $P$. falciparum in vitro pada pemberian berbagai dosis etil - $p$ metoksi sinamat (gb kiri) dari K. galanga dan klorokuin klorokuin (gb kiri)

Penentuan $\mathrm{K}_{\mathrm{I}}$ senyawa uji terhadap aktivitas enzim ATPase

Metode penentuan tetapan hambatan $\mathrm{K}_{\mathrm{I}}$ senyawa uji pada aktivitas enzim terhadap substrat adalah sama seperti penentuan $\mathrm{K}_{\mathrm{m}}$ ATPase. Langkah pertama persiapan percobaan yaitu: Selain Pembuatan larutan buffer suksinat, enzim ATPase, ATP, Amonium dan fenilhidrazin dihidoklorida. Untuk larutan inhibitor senyawa uji $1 \mathrm{mgmL}^{-1}$ dibuat dalam dua konsentrasi yaitu pengenceran $10 x$ dan $25 x$.

Langkah kedua pelaksanaan percobaan untuk masing-masing senyawa uji (2 pengenceran) yaitu campuran: substrat ATP $(100,200,300,400$ dan $500 \mu \mathrm{L}), 50 \mu \mathrm{L}$ senyawa uji, enzim ATPase $(50 \mu \mathrm{L})$ dan ditambah buffer suksinat $(40 \mathrm{mM})$ untuk menyamakan volume, diinkubasikan dalam waterbath pada suhu $30^{\circ} \mathrm{C}$ selama 10 menit. Langkah selanjutnya dilakukan cara yang sama seperti pada penentuan $\mathrm{K}_{m}$ ATPase.

Langkah akhir penentuan tetapan $K_{1}$ ATPase, dilakukan dengan menganalisis data hubungan laju $(1 / v)$ terhadap $1 /(\mathrm{S})$ dari data variasi konsentrasi substrat yang mengandung Inhibitor.

\section{Hasil dan Pembahasan}

Aktivitas etil- $p$-metoksisinamat, terhadap pertumbuhan $P$. falciparumin vitro;

Uji aktivitas antimalaria etil- $p$ metoksisinamat dan klorokuin sebagai kontrol positif menunjukkan adanya hambatan di atas $50 \%$ terhadap pertumbuhan $P$. falciparum in vitro, (Gambar 2).

Analisis inhibisi menunjukkan bahwa etil- $p$ metoksisinamat aktif menghambat pertumbuhan $P$. falciparum in vitro dengan $\mathrm{IC}_{50}$ sebesar $19,5 \mathrm{ngmL}^{-1}$ atau $94,6 \mathrm{nM}$, jika dilihat dari efektifitasnya masih jauh lebih kecil dibandingkan dengan klorokuin 0,20 $\mathrm{ngmL}^{-1}$ atau 3,0 nM.

E-p-metoksisinamat diperoleh dari fraksi etil asetat rimpang $K$. galanga. Senyawa tersebut memperlihatkan aktivitas antimalaria in vitro. Hasil ini menyiratkan bahwa etil-pmetoksisinamat dapat berperan sebagai pra zat antimalaria. Dari hasil penelitian [11] diketahui adanya aktivitas antimalaria dari derivat asam sinamat [ $\alpha$-Siano- $\beta$ (1-fenilindol3-il)akrilat] UK-5099, $\quad \alpha$-Siano-3hidroksisinamat $\alpha-\mathrm{C} 3 \mathrm{HC}$, dan $\alpha$-Fluorosinamat $\alpha-F C]$. Derivat asam sinamat tersebut diketahui merupakan inhibitor transpor monokarboksilat yang melintasi plasma dan membran Selain menghambat eksresi asam laktat, derivat asam sinamat juga menghambat produksi ATP dan penggunaannya oleh sel host Tidak tertutup kemungkinan bahwa etil-p-metoksisinamat dapat mempunyai efek seperti derivat asam sinamat lainnya. Selanjutnya bahwa diantara beberapa derivat asam sinamat yang bersifat non-polar memperlihatkan efek antimalaria paling poten. Penemuan ini menarik bila 
dilihat dari aktivitas antimalaria senyawa derivat asam sinamat, dimana senyawa etil $p$ -

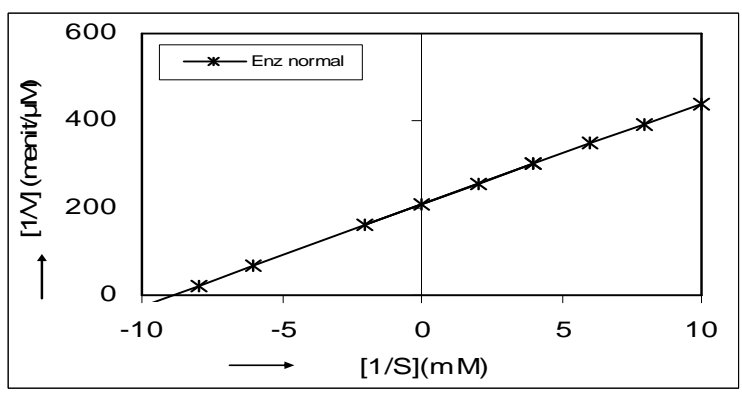

Gambar 3

Kurva aktivitas enzim ATPase tanpa inhibitor dengan substrat $\operatorname{ATP}(0,2 ; 0,4 ; 0,6 ; 0,8$ dan $1,0 \mu \mathrm{M})$.

metoksisinamat merupakan senyawa yang memperlihatkan aktivitas antimalaria yang paling poten. Dalam kaitan ini, etil $p$ metoksisinamat memperlihatkan aktivitas antimalaria in vitro, kemungkinan disebabkan oleh perbedaan polaritasnya [11] .

\section{Efek Senyawa Terhadap Enzim ATPase}

Kurva standar aktivitas ATPase. Uji aktivitas enzim ATPase terhadap substrat ATP sebagai diketahui bahwa aktivitas enzim ATPase pada perlakuan kontrol semakin meningkat seiring dengan bertambahnya konsentrasi substrat, ini dapat dilihat dari semakin meningkatnya serapan. Analisis regresi aktivitas ATPase dari data percobaan diperoleh kurva aktivitas enzim ATPase (Gambar 3) dengan nilai $R^{2}$ tingkat signifikansi sebesar 3,5\%.

Dari analisis regresi linier hubungan konsentrasi substrat dengan laju reaksi dalam keadaan tanpa inhibitor (Gambar 3), diketahui titik potong pada sumbu-y adalah $1 / \mathrm{V}_{\text {maks }}$ (207,2 mM $^{-1}$ menit) atau $\mathrm{V}_{\text {maks }}\left(4,8 \mu\right.$ Mmenit $^{-1)}$ dan titik potong pada sumbu-x adalah $-1 / \mathrm{K}_{\mathrm{m}}$ $(8,92 \mathrm{mM})$ atau $\mathrm{K}_{\mathrm{m}}(0,112 \mathrm{mM})$.

Efek inhibisi etil- $p$-metoksisinamat. Etil- $p$ metoksisinamat menunjukkan efek inhibisi terhadap aktivitas ATPase. Hasil analisis regresi linier dengan konsentrasi (4,9 dan 12,1 $\mu \mathrm{M})$ diperoleh tingkat signifikansi 2,2\% (signifikan), dan 0,7\% (sangat signifikan).

Dari hubungan konsentrasi substrat dengan laju reaksi, adanya inhibitor dan konsentrasi standar (tanpa inhibitor). diketahui menunjukkan efek inhibisi non-kompetitif (Gambar 4). Pada gambar tersebut diketahui ada tiga titik potong pada sumbu-y adalah $1 / \mathrm{V}_{\text {maks }}$ standar, konsentrasi etil- $p$ metoksisinamat $(4,9 \mu \mathrm{M})$ dan $(12,1 \mu \mathrm{M})$, dengan titik potong $\left(1+\mathrm{l} / \mathrm{K}_{\mathrm{m}}\right) / \mathrm{V}_{\text {maks }}(217,7$ dan $237,5 \mathrm{mM}^{-1}$ menit) atau laju maksimum $\mathrm{V}_{\text {maks }}$ $\left(4,6\right.$ dan 4,2 $\left.\mu \mathrm{Mmen}^{-1}\right)$. Berdasarkan data tersebut ke tiga garis berpotongan pada satu titik yang menunjukkan non-kompetitif dengan nilai $K_{l}(0,09 m M)$.

Parasit malaria $P$ falciparum tumbuh dalam eritrosit manusia, untuk mendapatkan protein, lipid dan sumber mengambil dari eritrosit melalui saluran membran parasit, dengan sitim pompa yang melibatkan enzim $\mathrm{Na}^{+}-\mathrm{K}^{+}-$ ATPase, atau enzim tipe $-\mathrm{V} \mathrm{H}^{+}$ATPase yang sensitif terhadap concanamisin A., $\mathrm{H}^{+-}$ pirofosfatase $\left(\mathrm{H}^{+}\right.$-PPase) yang dapat dihambat dengan $\mathrm{NaF}$, bergantung pada $\mathrm{K}^{+}$dan $\mathrm{Mg}^{2+}$ pirofosfat komplek [12]

Dalam percobaan dengan pendekatan menggunakan ATP dan ATPase mamalia, diketahui ada aktivitas sangat signifikan antara substrat dengan enzim, walaupun konsentrasi enzim sangat kecil. Keadaan ini membuktikan ATPase sangat aktif menghidrolisis ATP tiap kenaikan konsentrasi substrat tersebut.

Dalam sel eukariotik ATPase termasuk golongan enzim hidrolisis, enzim ini bekerja spesifik yaitu menghidrolisis ATP $\rightarrow$ ADP $+\mathrm{P}_{\mathrm{i}}$, dan menghasilkan energi. ATPase berperan penting pada sistim transporter membran sel yang tersusun protein, proses transport aktif (simport dan antiport) memerlukan energi hasil hidrolisis pemutusan ikatan fosfodiester dalam molekul ATP dan pirofosfat.

Senyawa etil- $p$-metoksi-sinamat, hasil isolasi dari rimpang $K$. galanga menpunyai potensi antimalaria, menunjukkan efek inhibisi 
non-kompetitif terhadap ATPase, Terjadi inhibisi non-kompetitif disebabkan tiga

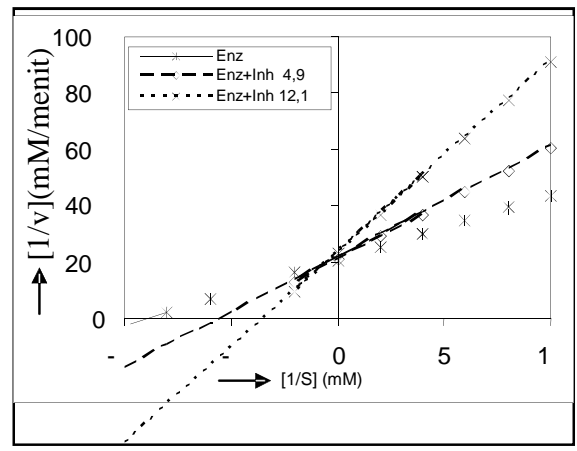

Gambar 4

Kurva inhibisi non-kompetitif senyawa etil- $p$ metoksisinamat hasil isolasi dari $K$. galanga terhadap aktivitas enzim ATPase.

senyawa sebagai inhibitor memiliki struktur utama sinamat, struktur tersebut sangat berbeda dengan struktur ATP yang mempunyai gugus utama nukleosida. Akibat perbedaan struktur, persaingan interaksi antara inhibitor dengan substrat ATP terhadap ATPase, tidak bersaing pada satu tempat aktif melainkan berikatan pada sisi lain selain sisi tempat substrat.

Terbentuknya ikatan inhibitor-enzimsubstrat (I-E-S) dapat mengubah konformasi molekul enzim, sehingga mengakibatkan inaktivasi dapat balik sisi katalitiknya (Devlin, 2002). Dalam percobaan yang mengalami interaksi adalah gugus ester dari etil- $p$ metoksisinamat, Dilihat dari nilai signifikansi rata-rata diketahui etil- $p$-metoksisinamat menunjukkan nilai signifikan. Hal ini terungkap bahwa pada proses metabolism, etil-p-metoksisinamat efektif menghambat aktivitas ATPase.

Hubungan Antara Senyawa, Parasit dan Aktivitas Enzim

Meskipun uji aktivitas enzimatik ini tidak dilakukan pada parasit malaria secara langsung, sebagian dari hasil di atas, khususnya yang berkaitan dengan senyawa derivat asam sinamat memperlihatkan adanya hambatan terhadap enzim ATPase. Senyawa derivat asam sinamat telah dikenal luas sebagai inhibitor dari transpor senyawa monokarboksilat pada membran sel dan membran mitokondria. Senyawa derivat asam sinamat yang berbeda telah dilaporkan menghambat produksi ATP dan penggunaan ATP pada sel host (Kanaani and Ginsburg, 1992), efek tersebut pada parasit malaria masih belum jelas (ambiguous) dan tampaknya diakibatkan oleh hambatan senyawa tersebut pada proses-proses di dalam sel yang memerlukan ATP. Dengan demikian etil-p-metoksi-sinamat tersebut dapat mengungkapkan inhibisi non-kompetitif pada aktivitas enzim ATPase. Berdasarkan uraian tersebut nampak bahwa, sisi aktif senyawa etil-p-metoksi-sinamat adalah gugus karbonil, sedangkan gugus yang berperan besar pada aktivitas antimalaria adalah gabungan antara gugus ester dan metoksi, bila salah satunya hilang maka aktivitasnya akan turun.

Senyawa hasil isolasi yang diinjeksikan secara i.p, langsung mengalami proses dalam sistem biomolekul yang sangat kompleks. Ada dua kemungkinan mekanisme yang terjadi dalam sistem sel hidup. Pertama, molekulmolekul mengalir dalam aliran darah ke seluruh tubuh, dalam perjalanannya sebagian langsung masuk ke dalam sitoplasma eritrosit atau mengalami metabolisme terlebih dahulu di dalam sel hati, yang selanjutnya berinteraksi dengan parasit. Kedua, sebagian lainnya mengalami proses sinergis dengan molekulmolekul atau biomolekul dalam aliran darah.

Etil-p-metoksisinamat, diketahui menginhibisi secara non-kompetitif terhadap enzim ATPase serta mampu menghambat perumbuhan parasit secara in vitro. Dalam hal ini Tidak tertutup kemungkinan di dalam eritrosit yang berparasit malaria, terjadi mekanisme kerja senyawa menghambat aktivitas enzim ATPase dan terhadap enzim lain yang ada dalam parasit malaria $P$. falciparum [8]. Etil-p-metoksisinamat 
menembus membran eritrosit berparasit melalui NPP besama-sama nutrisi lain, tapi mungkin juga dapat terjadi pemblokiran saluran selektif-anion. Kemungkinan lain adalah, senyawa etil-p-metoksisinamat langsung masuk ke sitoplasma parasit dan berinteraksi dengan $\mathrm{Na}^{+} \mathrm{K}^{+} \mathrm{ATP}$ ase atau $\mathrm{V}$ $\mathrm{H}^{+}$ATPase. Enzim tersebut digunakan parasit dalam menginfeksi eritrosit [13].

Dari uji inhibisi terhadap aktivitas ATPase, senyawa etil- $p$-metoksisinamat berinteraksi non-kompetitif menyebabkan enzim mengalami perubahan konformasi dan active site dari enzim tidak dapat berinteraksi dengan ATP sehingga menyebabkan tidak dihasilkannya energi untuk mendorong $\mathrm{Na}^{+}$ keluar membran dan $\mathrm{K}^{+}$masuk ke dalam membran dan menyebabkan pertumbuhan parasit terhambat. Interaksi ini dapat terjadi dalam intraeritrosit atau plasma membran dalam parasit yang mengandung derivat ATPase yang berperan merubah ATP/ADP. Terhambatnya pembentukan ADP dapat menghambat terbentuknya energi yang diperlukan, proses pompa $\mathrm{Na}^{+}$atau pompa $\mathrm{H}^{+}$, selanjutnya laju pertumbuhan parasit dapat menurun bahkan dapat terhenti.

Walaupun percobaan ini menggunakan enzim dan substrat dari mamalia, tetapi merupakan pendekatan yang menarik karena enzim ATPase dan enzim-enzim lainnya telah banyak ditemukan dan diteliti aktivitasnya di dalam host eritrosit dan parasit. Dengan terungkapnya aktivitas Etil-p-metoksisinamat terhadap parasait $P$. falciparum dan enzim ATPase adalah hal yang baru dalam mekanisme kerja enzim tersebut, menarik dan membuka jalan bagi penelitian lebih lanjut untuk mengetahui secara rinci mekanisme penghambatan senyawa tersebut pada parasit malaria.

\section{Kesimpulan}

Berdasarkan hasil percobaan dan pembahasan dapat diambil kesimpulan sebagai berikut:

1. Etil p-metoksisinamat dapat menghambat pertumbuhan Plasmodium falciparum yang ditunjukan dengan pertumbuhan parasit $50 \%$ sebesar $19,5 \mathrm{ngmL}^{-1}$ atau 94,6 nM.

2. Etil p-metoksisinamat dapat menghambat aktivitas enzim sangat signifikan dengan tingkat signifikansi $2,2 \%$ dan $0,7 \%$ serta menunjukkan hambatan non-kompetitif non-kompetitif dengan nilai $K_{1}(0,09 \mathrm{mM})$.

3. Dengan terungkapnya aktivitas Etil- $p$ metoksisinamat terhadap parasait $P$. falciparum dan enzim ATPase adalah hal yang baru dalam mekanisme kerja enzim tersebut, menarik dan membuka jalan bagi penelitian lebih lanjut untuk mengetahui secara rinci mekanisme penghambatan senyawa tersebut pada parasit malaria.

\section{Penghargaan}

Penulis mengucapkan terima kasih khususnya kepada direktur Eijkman Institute for Moleculer Biology di Jakarta yang telah memberi biakan parasit $P$. berghei. Terima kasih kepada Kepala Laboratorium Penelitian Pascasarjana FMIPA UNPAD beserta stafnya staf lain telah memberi izin penelitian, menbantu kelancaran dan memberi fasilitas yang ada dilembaga tersebut. Terima kasih disampaikan pula Kepala Laboratorium IImuIImu Dasar FKIP UNIKU beserta staf, atas segala Fasilitas dan bantuan pelaksanaan penelitian. 


\section{Daftar Pustaka}

[1] WHO., 2005. World Malaria Report 2005. WHO Library Cataloguing-in-Publication Data.

[2] Muis, A., Sudjanaatmadja, U.M.S., Supriyatna dan Syafruddin. 2003. Aktivitas antimalaria dari ekstrak etanol rimpang Kaemferia galanga L. Simposium Nasional Kimia Bahan Alam XIII, Bandung.

[3] Darwis S., 1990. Isolasi dan transformasi etil p-metoksisinamat dari Kaempfaria galanga Linn. Tesis. Fakultas Pasca Sarjana. ITB, Bandung

[4] Jansen, C.J. and Waters, A.P., 2002. The Plasmodium berghei research model of malaria, $\mathrm{Http} / \mathrm{www}$ yahoo.com. 22-6-2004

[5] Bourdy, G., Oporto, P., Gimenez, A. and Deharo, E., 2004. A search for natural bioactive compounds in Bolivia through a multidisciplinary approach Part VI. Evaluation of the antimalarial activities of plants used by Isoceno-Guarani Indians. Journal of Ethnopharmacology. 93: 269-277.

[6] Kalauni, S.N., Suresh, A., Yasuhiro, T., Arjun, H.B., Thein, Z.L., Puji, B.S.A., Din, S., and Shigetoshi, K., 2006. Antimalarial activity of cassane- and norcassane-type diterpenes from Caesalpinia crista and their structure-activity relationships. Biological Pharmacology Bulletin. 29(5): 1050-1052.

[7] Delvin, T.M., 2002. Textbook of Biochemistry with Clinical Corelations. $5^{\text {th }}$. Wiley-Liss, New York.

[8] Elandallaussi, L.M. and Smith, P.J., 2002. Preparation of pure an intact Plasmodium falciparum plasma membran vesicles and partial characterisation of the plasma membran ATPase. Malaria Journal. 1 (6): 1475-2875.

[9] Trager, W., and Jensen, J.B., 1976. Human malaria parasites in continous culture science, in Methods in Malaria Research, $3^{\text {rd }}$ Ed. Edited by Martha sclichherle, MatsW., Hedvig P,. Arthur Scherf, Manassas, Virginia.

[10] Kernen, P., Agoesti, R.D., Strasser, R.J., and Darszon, A., 1997. ATPase activity of thylakoid in CTAB-hexanol-octane low water system. Biochimica et Biophysica Acta. 1321: 71-78.

[11] Kanaani, J., and Ginsburg, H., 1992. Effects of cinnamic acid derivatives on in vitro growth of Plasmodium falciparum and on the permeability of the membrane of malaria-infected erythrocytes. Antimicrobial Agents Chemotheraphy. 36: 1102-1108.

[12] Saliba, K.J., Allen, R.J.W., Zissis, S., Bray,P.G., Ward, S.A. and Kirk, K., 2003. Acidification of the malaria parasite's digestive vacuole by a $\mathrm{H}^{+}$-ATPase and a $\mathrm{H}^{+}$-pyrophosphatase. Journal Biooganic Chemistry, 278 (8), 5605-5612.

[13] Marchesini, N., Mauricio, V., Shuhong, L., Silvia, N.J.M. and Roberto, D., 2005. A malaria parasite-encoded vacuola $\mathrm{H}^{+}$-ATPase is targeted to the host erythrocyte. Journal of Biologycal Chemistry. 280 (44): 36841-36847. 